\title{
IDENTIFIKASI PENALARAN ALJABAR MAHASISWA DALAM MENYELESAIKAN MASALAH RELASI REKURSIF MENGGUNAKAN ALAT PERAGA MENARA HANOI DITINJAU DARI GAYA BELAJAR
}

\section{Identification of Student Algebraic Reasoning in Solving Recursif Relation Problem Using Hanoi Tower Props Based on Learning Style}

\author{
Nur Fitriyah Indraswari ${ }^{*}$, Siti Zakiyah ${ }^{2}$ \\ 1,2 Program Studi Pendidikan Matematika, STKIP PGRI Sumenep \\ Jln. Trunojoyo Gedungan Sumenep, 69451, Indonesia \\ e-mail:1*nurfitriyah@stkippgrisumenep.ac.id; ${ }^{2}$ sitizakiyah@stkippgrisumenep.ac.id ; \\ Corresponding Author *
}

\begin{abstract}
Abstrak
Penelitian ini bertujuan untuk mengidentifikasi level penalaran aljabar mahasiswa dalam menyelesaikan masalah relasi rekursif menggunakan alat peraga menara hanoi ditinjau dari gaya belajar. Penelitian ini termasuk jenis penelitian deskriptif eksploratif dengan pendekatan kualitatif. Intrumen dalam penelitian ini terdiri dari angket gaya belajar, Tes Kemampuan Matematika, Tugas Pemecahan Masalah, dan wawancara berbasis tugas. Penelitian diawali dengan pemberian tes kemampuan matematika dan agket gaya belajar kepada 8 orang mahasiswa semester VI prodi pendidikan matematika STKIP PGRI Sumenep untuk mendapatkan tiga subjek yang masing-masing bergaya belajar visual, auditori, dan kinestetik dengan kemampuan matematika setara serta berjenis kelamin sama. Setelah itu dilanjutkan dengan pemberian tugas pemecahan masalah dan wawancara berbasis tugas sebanyak dua kali. Triangulasi waktu digunakan untuk mengecek keabsahan data. Teknik analisis data terdiri dari 5 tahap, yaitu kategorisasi data, reduksi data, penyajian data, penafsiran data, dan penarikan kesimpulan Hasil penelitian menunjukkan bahwa subjek visual berada lebih tinggi dari level 2 tetapi belum mencapai level 3, subjek auditori berada pada level 2, dan subjek kinestetik berada pada level 3. Ketiga subjek sudah sampai pada tahap menyelesaikan permasalahan, namun yang bisa menyelesaikan permasalahan sampai menemukan solusi akhir hanya subjek kinestetik. Implikasi penelitian dalam pembelajaran yaitu pengajar dapat lebih mudah merancang pembelajaran yang sesuai dengan gaya belajar sehingga dapat mengasah penalaran aljabar mahasiswa.
\end{abstract}

Kata Kunci : level penalaran aljabar, gaya belajar,menara hanoi, relasi rekursif.

\begin{abstract}
This study aims to identify the level of students' algebraic reasoning in solving recursive relation problems using tower hanoi props in terms of learning styles. This research is a descriptive exploratory research with a qualitative approach. The instruments in this study consisted of learning style questionnaires, Mathematics Ability Tests, Problem Solving Tasks, and task-based interviews. The research begins with giving tests of mathematical ability and learning style agket to 8 semester VI students of the STKIP PGRI Sumenep mathematics education study program in Sumenep to obtain three subjects, each with visual, auditory and kinesthetic learning styles with equal mathematical abilities and of the same gender. After that, it was followed by giving problem solving tasks and taskbased interviews twice. Time triangulation is used to check the validity of the data. The data analysis technique consists of 5 stages, namely data categorization, data reduction, data presentation, data interpretation, and drawing conclusions. The results show that the visual subject is higher than level 2 but has not reached level 3, the auditory subject is at level 2, and the kinesthetic subject is at level 3. The three subjects have reached the stage of solving the problem, but the one who can solve the problem until they find the final solution is only the kinesthetic subject. The implication of research in learning is that teachers can more easily design learning according to their learning styles so that they can hone students' algebraic reasoning.
\end{abstract}

Keywords: Algebraic reasoning level, Learning style, Hanoi tower, Recursif relation 


\section{PENDAHULUAN}

Penalaran merupakan salah satu keterampilan yang harus dimiliki dan dikuasai mahasiswa untuk dapat berpikir matematis. Penalaran memiliki makna berpikir logis dalam menarik suatu kesimpulan. Kesimpulan dalam konteks ini berupa penyelesaian soal dan berpikir logis dilihat dari poses penyelesaian masalah. Penalaran matematika dapat dijadikan fondasi dalam memahami dan doing matematika serta bagian integral dari pemecahan masalah [1]. Selain itu, penalaran dapat secara langsung meningkatkan hasil belajar peserta didik, yaitu jika peserta didik diberi kesempatan untuk menggunakan keterampilan bernalarnya dalam melakukan pendugaan-pendugaan berdasarkan pengalaman sendiri, sehingga peserta didik akan lebih mudah memahami konsep [2]. Salah satu jenis penalaran yang berkaitan dengan simbol-simbol dan generalisasi yaitu penalaran aljabar. Penalaran aljabar adalah berpikir berdasarkan kaidah matematika untuk menarik suatu kesimpulan yang di dalamnya terdapat kegiatan mencari dan mengenali pola dari suatu permasalahan matematika serta menyusun generalisasinya menggunakan simbol. Penalaran ajabar penting dipelajari karena merupakan dasar dari semua pemikian matematika, termasuk aritmetika yang memungkinkan seseorang untuk mengeksplorasi struktur matematika [3]. Namun pada kenyataanya, masih banyak mahasiswa yang belum bisa bernalar aljabar, salah satu contohnya pada mata kuliah yang diampu peneliti yaitu matematika diskrit materi relasi rekursif. Mahasiswa masih kesulitan menterjemahkan suatu permasalahan ke dalam bentuk relasi rekursif melalui pola-pola yang terbentuk sehingga berdampak pada cara mereka dalam menyelesaikan masalah.

Berdasarkan kondisi di lapangan, banyak mahasiswa yang masih kesulitan dalam memecahkan masalah pada mata kuliah matematika diskrit utamanya terkait penggunaan simbol-simbol dan bagaimana mengoperasikannya. Selain itu, mahasiswa juga mengalami kesulitan untuk menterjemahkan suatu masalah ke dalam bentuk model matematika. Matematika diskrit merupakan salah satu mata kuliah wajib di prodi pedidikan matematika STKIP PGRI Sumenep yang memberikan landasan matematis untuk mata kuliah lain di rumpun ilmu matematika. Terdapat beberapa manfaat mempelajari matematika diskrit, diantaranya yaitu dapat melatih daya berpikir abstrak, melatih logika berpikir, dan melatih analisis pemecahan masalah sehingga mahasiswa terbiasa memecahkan permasalahan secara lebih kritis dan rasional [4]. Namun, pada kenyataannya masih banyak mahasiswa yang kesulitan dalam mempelajari matematika diskrit. Salah satu alasan mengapa sulit mendefinisikan matematika diskrit karena mata kuliah tersebut merangkum sejumlah topik besar matematika dalam kombinatorial, logika, graf, termasuk dalam payung diskrit antara lain ilmu komputer, aljabar abstrak, teori bilangan, teori permainan, probabilitas, dan geometri [5].

Relasi rekursif merupakan salah satu materi dalam mata kuliah matematika diskrit yang juga dianggap sulit oleh mahasiswa. Hal ini berdasarkan angket respon mahasiswa tahun 2015/2016 terhadap perkuliahan relasi rekuresi, sebanyak 49,26\% menyatakan mampu memahami materi yang telah diajarkan, dan 25,76\% dapat mengaplikasikannya dalam kehidupan sehari-hari [6]. Berdasarkan hasil angket tersebut dapat diketahui bahwa sebagian besar mahasiswa hanya mampu memahami saja namun kesulitan dalam mengaplikasikannya dalam kehidupan sehari-hari.

Kesulitan memahami relasi rekursif dapat diminimalisir dengan cara mengetahui penalaran aljabar mahasiswa karena dengan cara tersebut pengajar bisa merancang metode pembelajaran yang tepat untuk mengembangkan penalaran aljabar. Penalaran aljabar melibatkan pembentukan perumuman/generalisasi dari pengalaman dengan bilangan dan perhitungan, memformalkan ide tersebut dengan menggunakan sistem simbol, dan mengeksplorasi konsep dari pola dan fungsi [3]. Untuk melatih penalaran aljabar mahasiswa juga diperlukan suatu alat peraga. Salah satu peranan alat peraga dalam pembelajaran matematika yaitu untuk meletakkan ide-ide dasar konsep pada peserta didik [7]. Salah satu alat peraga yang tepat untuk materi relasi rekursif yaitu menara hanoi. Alat peraga ini diharapkan dapat membantu mahasiswa menemukan pola, membuat generalisasi, dan menentukan relasi rekursif dari suatu permasalahan.

Alat peraga menara hanoi terdiri dari lempengan-lempengan berbentuk lingkaran dengan diameter yang berbeda-beda dan terdiri dari tiga tiang. Fungsi alat peraga menara Hanoi adalah untuk menemukan barisan bilangan dengan cara bermain. Cara penggunaanya adalah: Pindahkan susunan cakram dari satu tiang ke tiang yang lain dengan susunan seperti semula dengan aturan: Pindahkan hanya satu cakram pada setiap pemindahan serta cakram yang lebih besar tidak boleh diletakkan di atas cakram yang lebih kecil [8]. Pada penelitian ini, penggunaan alat peraga nantinya dapat mempermudah mahasiswa memahami konsep dan menentukan pola yang terbentuk serta menyelesaikan permasalahan tentunya berkaitan dengan relasi rekursif. Alat peraga menara hanoi ini dapat membantu mahasiswa untuk mengonkretkan keabstrakan matematika, sehingga dengan cara ini peneliti dapat lebih mudah mengidentifikasi level penalaran aljabar mahasiswa. 
Penalaran dan matematika merupakan dua hal yang tidak dapat dipisahkan Penalaran dapat digunakan untuk memahami konsep-konsep matematika, sementara penalaran dapat dilatih dan dikembangkan melalui aktivitas pembelajaran matematika. Sementara penyelesaian masalah merupakan salah satu aktivitas utama dalam pembelajaran matematika. Hal tersebut menunjukkan bahwa penalaran dapat dilihat melalui aktivitas penyelesaian masalah dalam pembelajaran matematika.

Penyelesaian masalah mempunyai fungsi penting dalam pembelajaran matematika karena dapat mempraktekkan dan mengintegrasikan konsep, teorema dan keterampilan yang telah dipelajari [9]. Pengguna akan penyelesaian masalah untuk mengembangkan penalaran aljabar dan menyajikan sudut pandang aljabar dari matematika dapat meningkatkan pemahaman jangka panjang bagi sebagian besar mahasiswa[10]. Biasanya, penalaran aljabar memerlukan pemikiran matematis yang lebih mendalam daripada aritmetika, dan penalaran aljabar mendorong penyelesaian masalah. Berdasarkan pendapat tersebut dapat dikatakan bahwa terdapat hubungan timbal balik antara penyelesaian masalah dengan penalaran aljabar [11]. Penyelesaian masalah dalam pembelajaran matematika dapat digunakan untuk mengembangkan penalaran aljabar siswa dan penalaran aljabar juga dapat mendorong siswa dalam penyelesaian masalah.

Kemampuan mahasiswa dalam menyelesaikan masalah selain dipengaruhi oleh penalaran aljabar juga dipengaruhi oleh cara yang cenderung mereka pilih dalam menerima dan mengolah informasi yang disebut gaya belajar. Gaya belajar secara tidak langsung akan berpengaruh terhadap kemampuan seseorang dalam menyelesaikan suatu permasalahan [12]. Hal ini mengindikasikan bahwa tiap mahasiswa mempunyai gaya belajar yang berbeda-beda dan ini berdampak pada cara mereka dalam menyelesaikan suatu masalah.

Beberapa penelitian terkait penalaran aljabar diantaranya tentang gaya kognitif visualizer dan verbalizer mempengaruhi number sense dan penalaran aljabar mahasiswa dalam menyelesaikan masalah [13]. Selain itu, penalaran aljabar dapat dikembangkan dengan cara mengembangkan generalisasi aritmetika, mengembangkan kemampuan berpikir divergen, dan melatih the algebraic habits of mind [14]. Bagaimanapun juga penelitian ini berbeda dengan penelitian sebelumnya karena tidak hanya sebatas mengetahui pengaruh gaya kognitif terhadap number sense dan penalaran aljabar mahasiswa maupun cara mengembangkan penalaran aljabar. Namun penelitian ini lebih berfokus untuk mendeskripsikan secara mendalam level penalaran aljabar siswa bergaya belajar visual, auditori, dan kinestetik dalam menyelesaikan masalah relasi rekursif menggunakan alat peraga Menara Hanoi. Indikator siswa bernalar aljabar pada penelitian ini diadaptasi dari level penalaran aljabar dalam menyelesaikan masalah yang dikemukakan oleh [15] meliputi memahami masalah, melakukan generalisasi, membuat bentuk umum, menyelesaikan masalah. Level penalaran aljabar terdiri dari level 0, level 1, level 2, dan level 3.

Berdasarkan latar belakang di atas yang intinya menyatakan pentingnya aljabar, namun terdapat masalah dalam pembelajaran aljabar yaitu rendahnya penalaran aljabar mahasiswa pada materi relasi rekursif. Sedangkan penalaran aljabar itu penting dan dipengaruhi oleh gaya belajar maka tujuan dalam penelitian ini adalah untuk mengidentifikasi level penalaran aljabar mahasiswa yang bergaya belajar visual, auditori, dan kinestetik dalam menyelesaikan masalah relasi rekursif menggunakan alat peraga menara Hanoi.

\section{METODE PENELITIAN}

Penelitian ini termasuk jenis penelitian deskriptif eksploratif karena peneliti ingin menggali informasiinformasi yang diperlukan dalam kegiatan penelitian secara mendalam. Pendekatan dalam penelitian ini yaitu kualitatif karena setting penelitian berlatar alami dan instrumen utama penelitian adalah peneliti sendiri. Analisis dilakukan secara mendalam pada subjek dengan gaya belajar auditori, visual dan kinestetik tentang level penalaran aljabar mereka dalam menyelesaikan masalah relasi rekursif menggunakan alat peraga. Penelitian dilaksanakan pada semester genap tahun ajaran 2019/2020. Penelitian diawali dengan pemberian angket gaya belajar kepada 8 orang mahasiswa semester 6 yang telah menempuh mata kuliah matematika diskrit. Sebanyak 4 mahasiswa bergaya belajar visual, 2 mahasiswa bergaya belajar auditori, dan 2 mahasiswa bergaya belajar kinestetik Kemudian tahap selanjutnya yaitu pemberian Tes Kemampuan Matematika (TKM) sebanyak 6 butir soal berbentuk uraian yang terdiri dari 2 soal kombinatorika dan 4 soal fungsi pembangkit. Setelah itu, diambil 3 mahasiswa dengan kriteria berjenis kelamin sama, berkemampuan matematika setara, dan masing-masing mewakili gaya belajar visual, auditori, dan kinestetik. Subjek penelitian berjenis kelamin sama supaya tidak ada faktor luar yang mempengaruhi selain gaya belajar karena perbedaan jenis kelamin dalam penyelesaian masalah matematika memiliki pengaruh yang cukup signifikan [16]. Selain itu, strategi penyelesaian masalah perempuan lebih beragam dibanding laki-laki [17]. 
Selanjutnya, peneliti memberikan Tugas Pemecahan Masalah (TPM) matematika kemudian diwawancarai. TPM diberikan sebanyak dua kali dengan rentang waktu seminggu dan soal yang setara. Hasil dari TPM dan wawancara berbasis tugas tiap mahasiswa selama dua kali kemudian dilihat kekonsistenannya menggunakan triangulasi waktu. Berdasarkan hasil triangulasi terdapat kekonsistenan data antara TPM dan wawancara berbasis tugas selama dua kali maka data dikatakan valid dan siap untuk dianalisis. Tahap analisis data pada penelitian ini terdiri dari 5 langkah yaitu kategorisasi data, reduksi data, penyajian data, penafsiran data, dan penarikan kesimpulan. Setelah dianalisis, diperolehlah data terkait identifikasi level penalaran aljabar mahasiswa dalam menyelesaikan masalah relasi rekursif mengggunakan alat peraga menara hanoi ditinjau dari gaya belajar. Adapun indikator level penalaran aljabar mahasiswa dalam menyelesaikan masalah relasi rekursif dapat dilihat pada tabel 1.

Tabel 1. Indikator Level Penalaran Aljabar Mahasiswa dalam Menyelesaikan Masalah Relasi Rekursif

\begin{tabular}{|c|c|c|c|c|c|}
\hline & Indikator & Level 0 & Level 1 & Level 2 & Level 3 \\
\hline $\begin{array}{l}\text { Memahami } \\
\text { masalah }\end{array}$ & $\begin{array}{l}\text { subjek menggunakan informasi yang } \\
\text { diberikan untuk menentukan langkah } \\
\text { penyelesaian masalah }\end{array}$ & $\sqrt{ }$ & $\sqrt{ }$ & $\sqrt{ }$ & $\sqrt{ }$ \\
\hline \multirow{4}{*}{$\begin{array}{l}\text { Melakukan } \\
\text { generalisasi }\end{array}$} & $\begin{array}{l}\text { subjek tidak memunculkan simbol } \\
\text { (menggunakan bahasa natural/apa } \\
\text { adanya) }\end{array}$ & $\sqrt{ }$ & $\sqrt{ }$ & $\sqrt{ }$ & $\sqrt{ }$ \\
\hline & $\begin{array}{l}\text { Hasil operasi dari operasi pada pola } \\
\text { tertentu/objek khusus? }\end{array}$ & $\sqrt{ }$ & $\sqrt{ }$ & $\sqrt{ }$ & $\sqrt{ }$ \\
\hline & $\begin{array}{l}\text { Subjek memunculkan simbol dan } \\
\text { mengetahui maknanya (menggunakan } \\
\text { bahasa simbol) }\end{array}$ & - & - & $\sqrt{ }$ & $\sqrt{ }$ \\
\hline & $\begin{array}{l}\text { Hasil diperoleh dengan memperhatikan } \\
\text { keteraturan pada pola untuk } \\
\text { menentukan perhitungan yang tepat }\end{array}$ & - & $\sqrt{ }$ & $\sqrt{ }$ & $\sqrt{ }$ \\
\hline \multirow{2}{*}{$\begin{array}{l}\text { Membuat } \\
\text { bentuk umum }\end{array}$} & $\begin{array}{l}\text { subjek dapat menyatakan } \\
\text { generalisasi dalam bentuk umum }\end{array}$ & - & - & $\sqrt{ }$ & $\sqrt{ }$ \\
\hline & $\begin{array}{l}\text { subjek melakukan operasi variabel pada } \\
\text { bentuk umum yang dibuat }\end{array}$ & - & - & - & $\sqrt{ }$ \\
\hline \multirow[b]{2}{*}{$\begin{array}{l}\text { Menyelesaikan } \\
\text { Permasalahan }\end{array}$} & subjek dapat menyelesaikan masalah & - & $\sqrt{ }$ & $\sqrt{ }$ & $\sqrt{ }$ \\
\hline & $\begin{array}{l}\text { subjek menggunakan bentuk umum } \\
\text { yang dibuat untuk menyelesaikan } \\
\text { masalah }\end{array}$ & - & - & $\sqrt{ }$ & $\sqrt{ }$ \\
\hline
\end{tabular}

Berikut merupakan permasalahan yang diberikan kepada tiap mahasiswa.

\section{Permasalahan}

Pada bidang papan ditancapkan tiga buah tiang dinamakan A, B, dan C. Sebanyak $n$ buah cakram berdiameter berbeda diletakkan pada salah satu tiang secara tersusun dari bawah ke atas, dari cakram diameter terkecil. $a_{n}$ menyatakan banyak cara sesedikit mungkin untuk memindahkan menara dengan $n$ cakram. Menara akan dipindahkan ke dua tiang lain, dengan aturan sebagai berikut.

i. $\quad$ Setiap kali memindah hanya boleh memindahkan satu cakram dari satu tiang ke tiang lain.

ii. Dalam susunan cakram, tidak boleh cakram berdiameter besar di atas cakram berdiameter kecil.

Tentukan:

a) Banyak langkah minimal untuk memindahkan 5 buah cakram. Jelaskan bagaimana cara kamu menemukannya.

b) Aturan yang membantumu untuk menemukan banyak langkah minimal memindahkan $n$ buah cakram. Jelaskan aturan yang telah kamu buat.

c) Relasi rekursif untuk menyatakan banyak langkah minimal untuk memindahkan $n$ buah cakram.

d) Solusi relasi rekursif yang telah kamu temukan pada poin c.

\section{HASIL DAN PEMBAHASAN}

Data telah dikatakan valid, maka langkah selanjutnya yaitu mengidentifikasi level penalaran aljabar mahasiswa berdasarkan indikator penalaran aljabar. Peneliti mengadaptasi indikator penalaran aljabar dari teori Ake et al. yang terdiri dari memahami masalah, melakukan generalisai, membuat bentuk umum, dan 
menyelesaikan permasalahan. Terdapat empat level primer penalaran aljabar, yaitu penalaran aljabar level 0 sampai dengan level 3. Penalaran aljabar level 0, subjek masih menggunakan operasi aritmetika dan belum menunjukkan generalisasi. Penalaran aljabar level 1, subjek berusaha melakukan generalisasi namun masih menggunakan bahasa aritmetika. Penalaran aljabar level 2, subjek sudah bisa melakukan generalisasi tetapi belum dapat melakukan operasi antar variabel. Penalaran aljabar level 3, subjek dapat menyatakan bentuk umum dengan variabel sebagai hasil dari generalisasi, dan dapat melakukan operasi pada variabel tersebut [5].

\subsection{Penalaran Aljabar Mahasiswa Bergaya Belajar Visual (SV) dalam Menyelesaikan Masalah Relasi Rekursif Menggunakan Alat Peraga Menara Hanoi}

SV terlihat terkejut saat menerima lembar tugas pemecahan masalah (TPM) dan alat peraga menara hanoi karena SV belum pernah menggunakan alat peraga tersebut sebelumnya. Kemudian, SV memperhatikan lembar TPM dan mulai mengoperasikan alat peraga menara hanoi. Awalnya SV merasa kebingungan, namun akhirnya lancar mengoperasikan dan merasa dengan adanya alat peraga menara hanoi dapat mempermudah dia untuk menyelesaikan TPM. Waktu yang diperlukan SV mengoperasikan alat peraga menara hanoi terbilang singkat yaitu sekitar 5 menit untuk menemukan banyak langkah minimal cakram yang ditanyakan. Pada saat menyelesaikan masalah relasi rekursif, SV terlihat beberapa kali melihat alat peraga dan lembar TPM secara bergantian. SV mencatat banyak langkah minimal memindahkan satu cakram sampai banyak cakram yang dikehendaki dalam bentuk diagram batang. Hal ini sejalan dengan [18] yang menyatakan bahwa seseorang bergaya belajar visual berpikir menggunakan gambar-gambar di otak dan belajar lebih cepat dengan menggunakan tampilan-tampilan visual, seperti diagram, buku pelajaran bergambar, dan video.

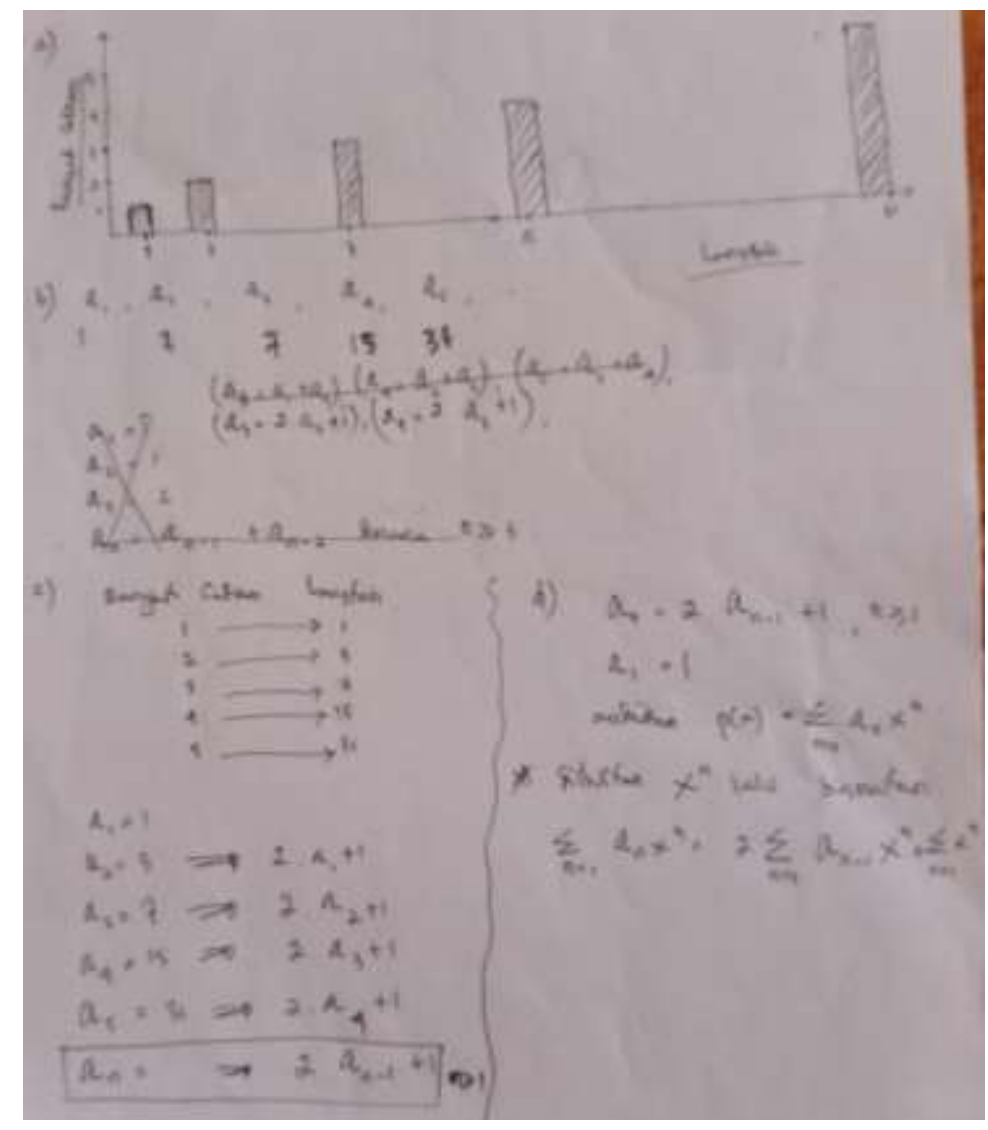

\section{Gambar 1. Hasil Pekerjaan SV dalam Menyelesaikan Masalah Rekursif pada TPM 2}

Pada indikator memahami masalah, SV dapat menjelaskan hal-hal apa saja yang diketahui dan ditanya. Selain itu, SV merepresentasikan banyak cakram dan banyak langkah minimal memindahkan cakram menggunakan diagram batang. Membuat representasi berdasarkan permasalahan sejalan dengan pendapat [13] yang menyatakan bahwa penggunaan berbagai macam representasi yang berkaitan dengan situasi kuantitatif dengan cara yang relasional merupakan salah satu ciri penalaran aljabar. SV juga menjelaskan bahwa banyak cakram dan banyak langkah minimal memindahkan cakram saling mempengaruhi untuk 
membentuk suatu pola. Untuk mencari banyak langkah minimal memindahkan cakram, SV mencoba memindahkan 1 buah cakram sampai banyak cakram yang diinginkan.

Pada indikator melakukan generalisasi, SV sudah menggunakan simbol-simbol seperti $a_{1}, a_{2}$ dan seterusnya. Pada hasil pekerjaannya juga tertera bahwa SV tersebut sudah menemukan pola yang terbentuk namun belum menuliskannya dalam bentuk $a_{n}$, hanya saja SV tersebut bisa menjelaskan jika peneliti menanyakan aturan antara banyak cakram dan banyak langkah minimal memindahkan cakram yaitu banyak langkah untuk memindahkan banyak cakram yang ditanyakan didapat dari banyak langkah minimal memindahkan cakram sebelumnya kali dua kemudian hasilnya ditambah satu. Awalnya SV masih bingung dari simbol yang digunakan tetapi pada akhirnya dia meyakini bahwa $n$ mewakili banyak cakram dan $a_{n}$ menyatakan banyak langkah minimal memindahkan $n$ buah cakram.

Pada indikator membuat bentuk umum, SV menyatakan dalam bentuk simbol-simbol dan sudah memunculkan simbol $a_{n}$ berikut syarat yang mengikutinya. SV dapat membuat relasi rekursif dari permasalahan yang diberikan. Pada saat ditanyakan perihal nilai $a_{0}$, SV tersebut menyatakan bahwa nilainya nol karena tidak ada cakram yang dipindahkan, namun lupa menuliskannya pada lembar TPM. SV berasumsi bahwa sutu relasi rekursif harus memiliki syarat atau batas nilai $\mathrm{n}$.

Pada indikator menyelesaikan masalah, SV mengalami kesulitan dalam menyelesaikannya. SV mengerti bahwa untuk menentukan solusi relasi rekursif ada sedikitnya dua cara yaitu menggunakan metode akar-akar karakteristik dan fungsi pembangkit. Untuk menyelesaikan permasalahan tersebut, SV memilih menggunakan metode fungsi pembangkit karena lebih mudah namun tetap tidak bisa mengerjakannya sampai menemukan hasil akhir.

Karakteristik yang muncul pada SV adalah sebagai berikut: (a) Menggunakan informasi yang diberikan untuk menentukan langkah penyelesaian masalah. (b) memunculkan simbol dan mengetahui maknanya serta memperhatikan keteraturan pola untuk menentukan perhitungan yang tepat. (c) Menyatakan hasil generalisasi dalam bentuk umum dengan melakukan operasi antar variabel. (d) Menentukan metode untuk menyelesaikan permasalahan namun belum bisa menemukan solusi akhir. Berdasarkan analisis karakteristik penalaran aljabar SV bergaya belajar visual dalam menyelesaikan masalah relasi rekursif menggunakan alat peraga menara hanoi, maka dapat dikatakan SV tersebut berada lebih tinggi dari level 2 namun belum mencapai level 3.

\subsection{Penalaran Aljabar Mahasiswa bergaya Belajar Auditori (SA) dalam Menyelesaikan Masalah Relasi Rekursif Menggunakan Alat Peraga Menara Hanoi}

SA merasa bingung saat mendapatkan lembar TPM dan alat peraga menara hanoi karena sebelumnya dia hanya mengetahui nama alat peraga tersebut tanpa tahu bagaimana cara mengoperasikannya. Selanjutnya SA mulai memahami isi dari lembar TPM dan langsung mencoba mengoperasikan alat peraga tersebut. SA membutuhkan waktu lumayan lama yakni sekitar kurang lebih 10 menit untuk menemukan banyak langkah minimal memindahkan cakram yang diinginkan. SA sering mengulang langkah-langkah memindahkan cakram. Pada saat mengerjakan TPM, SA seringkali terlihat berbicara dengan dirinya sendiri begitupun pada saat wawancara. SA merasa kebingungan dengan kalimat yang diungkapkannya dan beberapa kali mengulangi pernyataannya. Hal ini sejalan dengan [18] yang menyatakan bahwa seseorang bergaya belajar auditori mencerna makna yang disampaikan melalui pegucapan, suara, pitch (tinggi rendahnya), kecepatan berbicara dan hal-hal auditori lainnya. 


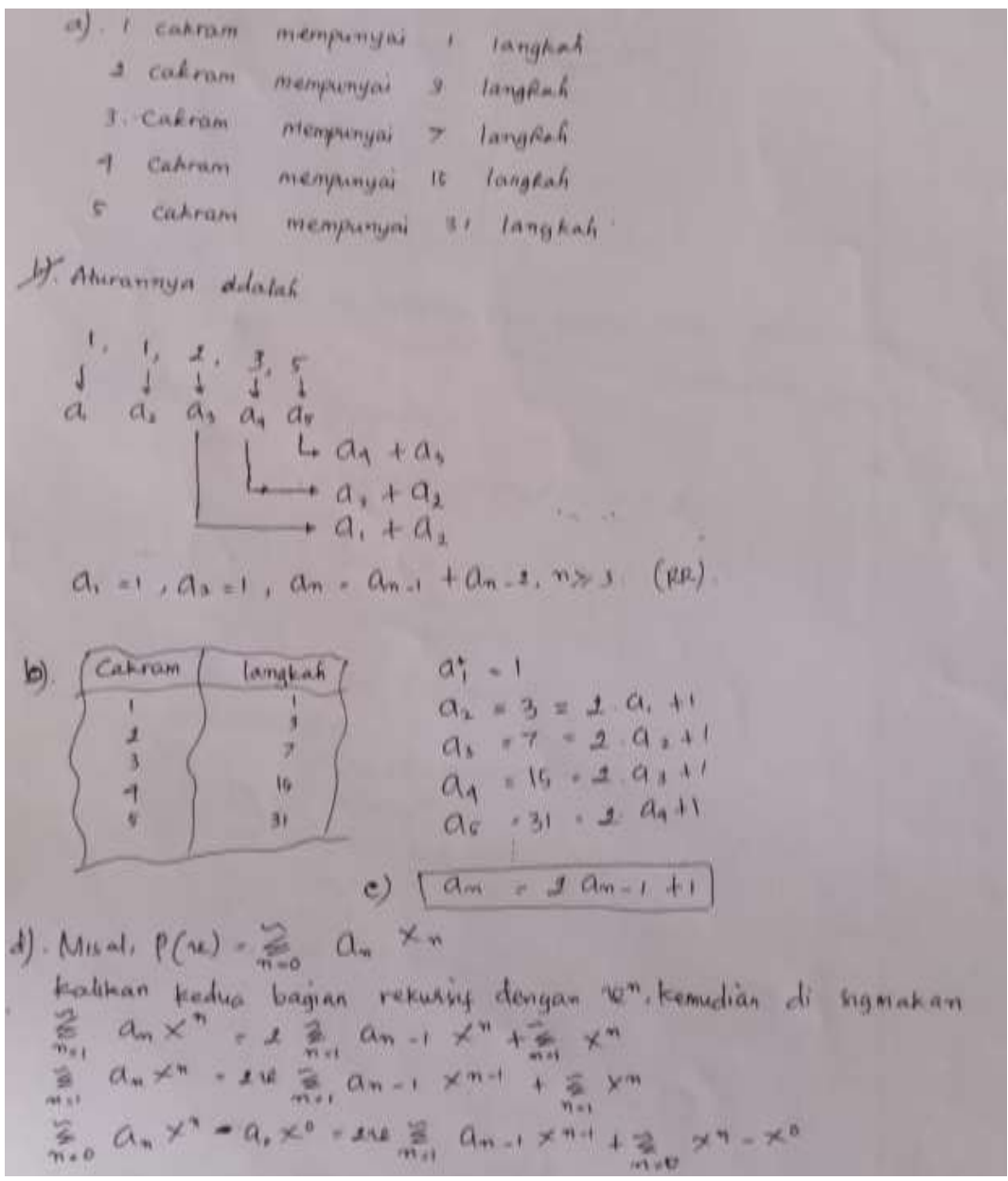

Gambar 2. Hasil Pekerjaan SA dalam Menyelesaikan Masalah Rekursif pada TPM 2

Pada indikator memahami masalah, SA dapat mengidentifikasi hal-hal apa saja yang diketahui dan ditanyakan pada TPM. Untuk menentukan banyak langkah minimal memindahkan sejumlah cakram yang diinginkan, SA mencoba memindahkan cakram tersebut dari 1 sampai dengan cakram yang diinginkan dan menuliskannya dalam bentuk tabel. Membuat representasi berdasarkan permasalahan sejalan dengan pendapat [13] yang menyatakan bahwa penggunaan berbagai macam representasi yang berkaitan dengan situasi kuantitatif dengan cara yang relasional merupakan salah satu ciri penalaran aljabar. SA menyatakan bahwa banyak cakram dan banyak langkah minimal memindahkan cakram membentuk suatu pola tertentu dan berkaitan satu sama lainnya.

Pada indikator melakukan generalisasi, SA sudah menggunakan simbol-simbol seperti $a_{1}$ yang melambangkan banyak langkah minimal memindahkan 1 buah cakram. pada hasil pekerjaannya, ditemukan bahwa SA tersebut sebenarnya telah menemukan pola yang terbentuk dari permasalahan tersebut namun belum menuliskannya dalam bentuk $a_{n}$. Namun, jika ditanyakan bagaimana mencari banyak langkah minimal untuk memindahkan 8 cakram, SA tersebut menjawab dengan tepat yaitu banyak langkah memindahkan 7 cakram kali 2 kemudian hasilnya ditambah 1. Hal ini mengindikasikan bahwa sebenarnya SA tersebut sudah menemukan aturan terkait permasalahan yang diberikan. Sejak awal, SA sudah paham bahwa $n$ menyatakan banyak cakram dan $a_{n}$ menyatakan banyak langkah minimal memindahkan $\mathrm{n}$ buah cakram.

Pada indikator membuat bentuk umum, SA menyatakannya dalam bentuk simbol dan memunculkan simbol $a_{n}$ namun tidak ada syarat yang mengikutinya. SA sebenarnya bisa membuat relasi rekursif dari suatu permasalahan, namun tidak sadar bahwa dalam relasi rekursif setidaknya ada satu syarat yang mengikuti. Hingga pada akhirnya, relasi rekursif yang telah SA tersebut buat tidak dilengkapi dengan syarat.

Pada indikator meyelesaikan masalah, SA sebenarnya mengetahui metode apa saja yang bisa digunakan untuk menentukan solusi relasi rekursif yaitu diantaranya metode akar-akar karakteristik dan fungsi pembangkit. SA bergaya belajar auditori ini memilih menggunakan metode fungsi pembangkit untuk menentukan solusi relasi rekursif yang telah dibuat sebelumnya, namun berhenti sebelum menemukan solusi akhir karena merasa kesulitan. 
Karakteristik yang muncul pada SA adalah sebagai berikut: (a) Menggunakan informasi yang diberikan untuk menentukan langkah penyelesaian masalah. (b) Memunculkan simbol dan mengetahui maknanya serta memperhatikan keteraturan pola untuk menentukan perhitungan yang tepat. (c) Menyatakan hasil generalisasi dalam bentuk umum, namun tidak memberikan prasyarat pada relasi rekursif yang terbentuk. (d) Menggunakan bentuk umum yang dibuat untuk menyelesaikan permasalahan namun tidak sampai pada hasil akhir meskipun metode yang dipilih tepat. Berdasarkan analisis karakteristik penalaran aljabar SA dalam menyelesaikan masalah relasi rekursif menggunakan alat peraga menara hanoi, maka dapat dikatakan SA tersebut berada pada level 2 .

\subsection{Penalaran Aljabar Mahasiswa bergaya Belajar Kinestetik (SK) dalam Menyelesaikan Masalah Relasi Rekursif Menggunakan Alat Peraga Menara Hanoi}

SK merasa terkejut saat diberikan lembar TPM dan alat peraga menara hanoi karena belum pernah mengenal alat peraga tersebut sebelumnya. SK kemudian membaca lembar TPM dan akhirnya mengetahui bahwa alat peraga tersebut dapat membantunya untuk menyelesaikan TPM. Selanjutnya, SK mencoba menggunakan alat peraga menara hanoi tersebut dengan waktu kurang dari 5 menit. Pertama, SK tersebut memindahkan 1 cakram, kemudian 2 cakram, sampai banyak cakram yang dikehendaki. Awalnya SK merasa kesulitan, namun pada akhirnya SK menyatakan telah menemukan tips dan trik memindahkan cakram dari tiang satu ke tiang lainnya. Pada saat mengerjakan TPM, terlihat beberapa kali SK menggerak-gerakkan bolpennya sambil mengotak-ngatik alat peraga menara hanoi. Begitupun pada saat wawancara, SK tidak hanya membaca dan memperhatikan jawaban tetapi sambil menunjukkan hasil pekerjaannya menggunakan bolpen dan menjelaskannya secara detail. Hal ini sejalan dengan [18] yang menyatakan bahwa seseorang bergaya belajar kinestetik lebih suka menangani, bergerak, menyentuh dan merasakan/mengalami sendiri, gerakan tubuh.

Pada indikator memahami masalah, SK dapat mengidentifikasi hal-hal apa saja yang diketahui dan ditanyakan pada TPM. Untuk menentukan banyak langkah minimal memindahkan banyak cakram yang diinginkan, SK mencoba memindahkan cakram dari banyak cakram 1 sampai banyak cakram yang diinginkan. SK beranggapan bahwa sesuai materi yaitu relasi rekursif maka nantinya yang dibicarakan adalah pola yang terbentuk, maka dia mencoba dari banyak cakram 1 sampai yang diinginkan untuk menemukan polanya. Hasil memindahkan 1 buah cakram sampai banyak cakram yang diinginkan, SK representasikan dalam bentuk tabel. Membuat representasi berdasarkan permasalahan sejalan dengan pendapat [13] yang menyatakan bahwa penggunaan berbagai macam representasi yang berkaitan dengan situasi kuantitatif dengan cara yang relasional merupakan salah satu ciri penalaran aljabar. SK berasumsi bahwa banyak cakram dan banyak langkah memindahkannya membentuk suatu pola dan berkaitan satu sama lainnya.

Pada indikator melakukan generalisasi, SK belum menuliskannya dalam bentuk simbol di lembar hasil TPM. Namun setelah diwawancarai SK menyatakan bahwa banyak langkah minimal memindahkan 3 buah cakram dapat disimbolkan dengan $a_{3}$, dan untuk memindahkan $n$ buah cakram disimbolkan dengan $a_{n}$. SK menyatakan bahwa untuk menentukan banyak langkah minimal memindahkan cakram yaitu dengan cara banyak langkah minimal memindahkan banyak cakram sebelumnya kali 2 kemudian hasilnya ditambah 1 . Hal ini mengimplikasikan sebenarnya SK sudah melakukan generalisasi.

Pada indikator membuat bentuk umum, SK menyatakannnya dalam bentuk simbol seperti $a_{n}, n$, dan juga syarat batas $n$ yang mengikuti. SK tidak menyertakan $a_{0}$ di relasi yang dibuat, namun jika ditanyakan banyak langkah minimal memindahkan 0 buah cakram yaitu 0 . SK mengatakan bahwa untuk menemukan pola, dia mengurutkan dari banyak langkah minimal memindahkan 1 cakram sampai $n$ cakram.

Pada indikator menyelesaikan masalah, SK menyatakan bahwa ada dua metode yang diketahui untuk menemukan solusi relasi rekursif yaitu metode akar-akar karakteristik dan metode fungsi pembangkit. Metode fungsi pembangkit dipilih SK untuk menemukan solusi relasi rekursif yang telah ditemukan karena dianggap lebih mudah untuk menyelesaikan relasi rekursif non homogen. SK menyelesaikan relasi rekursif sampai menemukan solusi akhir dengan menggunakan bentuk umum yang telah ditemukan. 


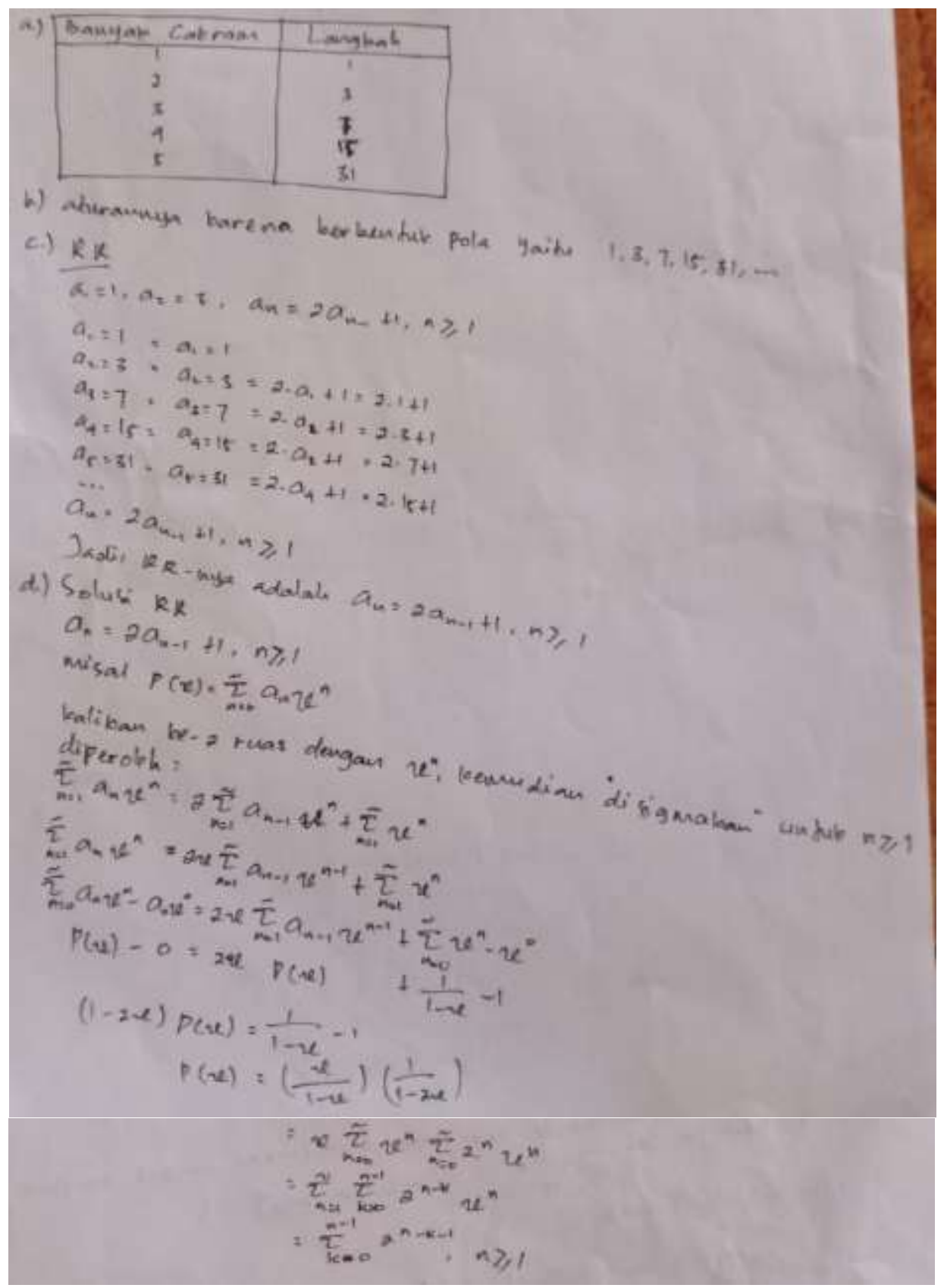

Gambar 3. Hasil Pekerjaan SK dalam Menyelesaikan Masalah Rekursif pada TPM 2

Karakteristik yang muncul pada SK bergaya belajar kinestetik adalah sebagai berikut: (a) Menggunakan informasi yang diberikan untuk menentukan langkah penyelesaian masalah. (b) Memunculkan simbol dan mengetahui maknanya serta memperhatikan keteraturan pola untuk menentukan perhitungan yang tepat. (c) Menyatakan hasil generalisasi dalam bentuk umum dengan memberikan syarat batas $n$ pada relasi rekursif yang terbentuk. (d) menggunakan bentuk umum yang dibuat untuk menyelesaikan permasalahan sampai menemukan solusi akhir relasi rekursif. Berdasarkan analisis karakteristik penalaran aljabar SK dalam menyelesaikan masalah relasi rekursif menggunakan alat peraga menara hanoi, maka dapat dikatakan SK tersebut berada pada level 3 .

\section{KESIMPULAN}

Berdasarkan hasil pengolahan data dan pembahasan diperoleh beberapa kesimpulan anara lain sebagai berikut.

1. SA membutuhkan waktu terlama dalam mengoperasikan alat peraga menara hanoi.

2. Pada indikator memahami masalah, ketiga subjek dapat memahami masalah dengan baik yang hubungannya dengan penggunaan alat peraga menara hanoi. 
3. Pada indikator melakukan generalisasi, ketiga subjek dapat menemukan keteraturan pola yang terbentuk dari hubungan antara banyak cakram dengan banyak langkah memindahkan cakram. Ketiga mahasiswa sudah menggunakan simbol-simbol, namun hanya mahasiswa bergaya belajar kinestetik yang langsung menuliskannya dalam bentuk $a_{n}$.

4. Pada indikator membuat bentuk umum, hanya SK yang dapat membuat relasi rekursif dilengkapi dengan syarat yang mengikutinya. Pada indikator menyelesaikan masalah, ketiga mahasiswa memilih metode yang sama dalam menentukan solusi relasi rekursif yaitu menggunakan metode fungsi pembangkit.

5. Diantara ketiga subjek, hanya SK yang dapat menyelesaikan relasi rekursif sampai menemukan solusi akhir. Hasil penelitian menunjukkan bahwa SV berada lebih tinggi dari level 2 tetapi belum mencapai level 3, SA berada pada level 2, dan SK berada pada level 3.

\section{DAFTAR PUSTAKA}

[1] M. A. Basir, "Kemampuan Penalaran Siswa dalam Pemecahan Masalah Matematis Ditinjau dari Gaya Kognitif," J. Pendidik. Mat. FKIP Unissula, vol. 3, no. 1, pp. 106-114, 2015.

[2] I. Saputri, E. Susanti, and N. Aisyah, "KEMAMPUAN PENALARAN MATEMATIS SISWA MENGGUNAKAN PENDEKATAN METAPHORICAL THINKING PADA MATERI PERBANDINGAN KELAS VIII DI SMPN 1 INDRALAYA UTARA,”J. Elem., vol. 3, no. 1, pp. 15-24, 2017.

[3] O. Ministry, Paying Attention to Algebraic Reasoning, K to 12. Toronto: Queen's printer for ontario, 2013.

[4] G. A. D. Sugiharni, "Pengembangan Modul Matematika Diskrit Berbentuk Digital dengan Pola Pendistribusian Asynchronous Menggunakan Teknologi Open Source," J. Nas. Pendidik. Tek. Inform., vol. 7, no. 1 (Maret 2018), pp. 58-72, 2018.

[5] L. Nuraini, I. Sujadi, and S. Subanti, "Penalaran Aljabar Siswa Kelas VII SMP Negeri 1 Margoyoso Kabupaten Pati dalam Pemecahan Masalah Matematika Tahun Pelajaran 2014/2015," J. Elektron. Pembelajaran Mat., vol. 4, no. 6, pp. 674-683, 2016.

[6] A. A. Wulandari, "Implementasi Worksheet ELPSA Pada Pembelajaran Relasi Rekurensi Implementation of ELPSA Worksheets on Recurrence Relation Learning," JIPM (Jurnal Ilm. Pendidik. Mat., vol. 6, no. 1, pp. 6067, 2017.

[7] S. Suwardi, M. E. Firmiana, and R. Rohayati, "Pengaruh Penggunaan Alat Peraga terhadap Hasil Pembelajaran Matematika pada Anak Usia Dini," J. Al-Azhar Indones. Seri Hum., vol. 2, no. 4, pp. 297-305, 2014.

[8] Nasaruddin, "Media dan Alat Peraga dalam Pembelajaran Matematika," al-Khwarizmi, vol. III, no. 2, pp. 2130, 2015.

[9] U. R. Jannah and H. Saleh, "Barriers to Student Thinking in Solving The Problem of Factoring Algebraic Form Based on The Level of Algebraic Thinking and Scaffolding," in Mathematics Education and Graph Theory, 2014, pp. 191-207.

[10] W. J. J. Windsor and M. Ed, "Algebraic Thinking- More to Do with Why, Than X and Y," 2010, pp. 592-595.

[11] S. R. Powel and L. S. Fuchs, "Does Early Algebraic Reasoning Differ as a Function of Students' Difficulty with Calculations versus Word Problems?," NIH Public Access, vol. 29, no. Agustus 2014, pp. 1-23, 2014.

[12] Na. M. Aljaberi, "University Students ' Learning Styles and Their Ability to Solve Mathematical Problems," Int. J. Bus. Soc. Sci., vol. 6, no. 4, pp. 152-165, 2015.

[13] M. Chrysostomou, D. Pitta-Pantazi, C. Tsingi, E. Cleanthous, and C. Christou, "Examining number sense and algebraic reasoning through cognitive styles," Educ. Stud. Math., vol. 83, no. 2, pp. 205-223, 2013.

[14] P. Andriani, "Penalaran Aljabar dalam Pembelajaran Matematika," J. Pendidik. Mat. Beta, vol. 8(1), no. Mei 2015, pp. 1-15, 2015.

[15] L. P. Ake, J. D. Godino, and M. Gonzato, "Proto-algebraic levels of mathematical thinking.," in Proceedings of the 37th Conference of the International 2 - 1 Group for the Psychology ofMathematics Education, 2013, no. August 2016, pp. 1-8.

[16] Z. Zhu, "Gender differences in mathematical problem solving patterns : A review of literature," Int. Educ. J., vol. 8, no. 2, pp. 187-203, 2007.

[17] O. B. Steinthorsdottir and B. Sriraman, Gender and Strategy Use in Proportional Situations: An Icelandic Study. Nordic Studies in Mathematics Education, 2007.

[18] A. M. Suhara, "Keefektifan Model Vak (Visualization Auditory Kinestetic) Dalam Pembelajaran Menulis Deskriptif (Studi Eksperimen Pada Siswa Kelas X SMA Negeri 1 Lawang Kidul,Sumatera Selatan) Universitas Pendidikan Indonesia | repository.upi.edu,” Bandung: Universitas Pendidikan Indonesia, 2013, pp. 285-309. 